\title{
Outcome of pregnancies in patients with complex pulmonary atresia
}

\author{
Ulrike Neumayer, Jane Somerville
}

\begin{abstract}
Objective-To evaluate the outcome of pregnancies in patients with complex pulmonary atresia, comparing those with and without previous radical surgical repair.

Design-A retrospective study of all pregnancies in women with complex pulmonary atresia registered on the Grown-up Congenital Heart Unit database between 1977 and 1994.
\end{abstract}

Setting-Referral centre for adolescents and adults with congenital heart disease.

Patients-Forty one pregnancies occurred in 15 patients. They were divided into two groups; group I, 26 pregnancies in nine patients before radical repair (cyanotic); group II, 15 pregnancies in seven women after radical surgical repair.

Results-In group I there were three terminations, 13 miscarriages, eight healthy children, and two neonatal deaths. Five children were born prematurely and all had low birthweights. In group II there were two miscarriages, 11 normal children, and two children with congenital heart disease. None was premature and all had normal birthweights. There were major complications in both groups: in group I there were two thromboembolic complications and one episode of heart failure; in group II there was one pulmonary embolism and one arrhythmic complication, five pregnancies in three patients were complicated by left ventricular failure that was persistent in one case and progressive in another, leading to death 13 months after delivery.

Conclusions-Patients with complex pulmonary atresia, with or without surgical repair, who have no or mild symptoms, can have successful pregnancies. Surgical repair decreases fetal complications significantly. In both groups thrombotic disorders and heart failure must be prevented. Patients with residual systemic-pulmonary collaterals after surgical repair are particularly at risk of left ventricular failure.

(Heart 1997;78:16-21)

Table 1 Summary of pregnancies in 15 patients with complex pulmonary atresia

\begin{tabular}{lccc}
\hline Outcome & Before repair & After repair & Total \\
\hline Termination & 3 & 0 & 3 \\
Miscarriage & 13 & 2 & 15 \\
Normal child & 10 & 11 & 21 \\
Child with CHD & 0 & 2 & 2 \\
Total & 26 & 15 & 41
\end{tabular}

CHD, congenital heart disease.
Keywords: pregnancy; complex pulmonary atresia; congenital heart disease

During the past 30 years the number of patients with complex congenital heart disease reaching the reproductive age has increased considerably because of improved management in infancy and childhood. Patients with complex pulmonary atresia - that is, pulmonary atresia with congenital systemic-pulmonary collaterals, particularly those with large pulmonary blood supply and mild cyanosis, may reach adult age without any previous surgical intervention or with the help of palliative procedures. Others, if deemed suitable, will have radical repair, with closure of the ventricular septal defect and reconstruction of the right ventricular outflow tract with homograft valved conduits or other types of conduit. ${ }^{1-3}$ This usually renders them acyanotic. The present study evaluated the outcome and complications of all pregnancies in patients with complex pulmonary atresia, with and without radical repair.

\section{Methods}

The data were collected from the Grown-Up Congenital Heart Unit database at the Royal Brompton Hospital in London. Patients were defined as having complex pulmonary atresia and included in the study if they had pulmonary atresia, large ventricular septal defect, and large congenital systemic-pulmonary collaterals. Unlike acquired collaterals, congenital collaterals are countable (one to six), arising mostly from the isthmus and descending aorta, frequently stenosed at their origin or within the hila, taking many, often bizarre, forms, and supplying a lobe, segment or whole lung or connecting directly with pulmonary arteries. ${ }^{4}$

The clinical records of all patients with complex pulmonary atresia who had had a pregnancy were reviewed. Obstetric reports were requested from the departments that had been supervising each pregnancy. For the miscarriages (all early, between eight and 12 weeks) and for three of the successful pregnancies (pregnancies 23, 24, and 41) no reports were available and the data were reconstructed from recordings in notes and from correspondence with the supervising hospital.

The patients were divided into two groups (table 1).

\section{GROUP I}

Nine patients without radical repair with 26 pregnancies constituted group I (table 2). Twenty five pregnancies (1-25) occurred in eight patients (cases $1-8$ ) who had not had any 
palliation, and there was one pregnancy (26) in a patient (case 9) with a previous Waterston shunt. All patients were cyanotic; systemic oxygen saturation (evaluated at cardiac catheterisation before or after the pregnancy with no clinical change and the same haemo- globin concentration since then) was $70 \%$ in one patient (case 7 ); $\sim 85 \%$ in five patients (cases $1,2,4,5$, and 6 ); and $\sim 90 \%$ in three patients (cases 3, 8, and 9). For each pregnancy the following data were noted: maternal age, haemoglobin concentration immediately

Table 2 Summary of pregnancies in group I

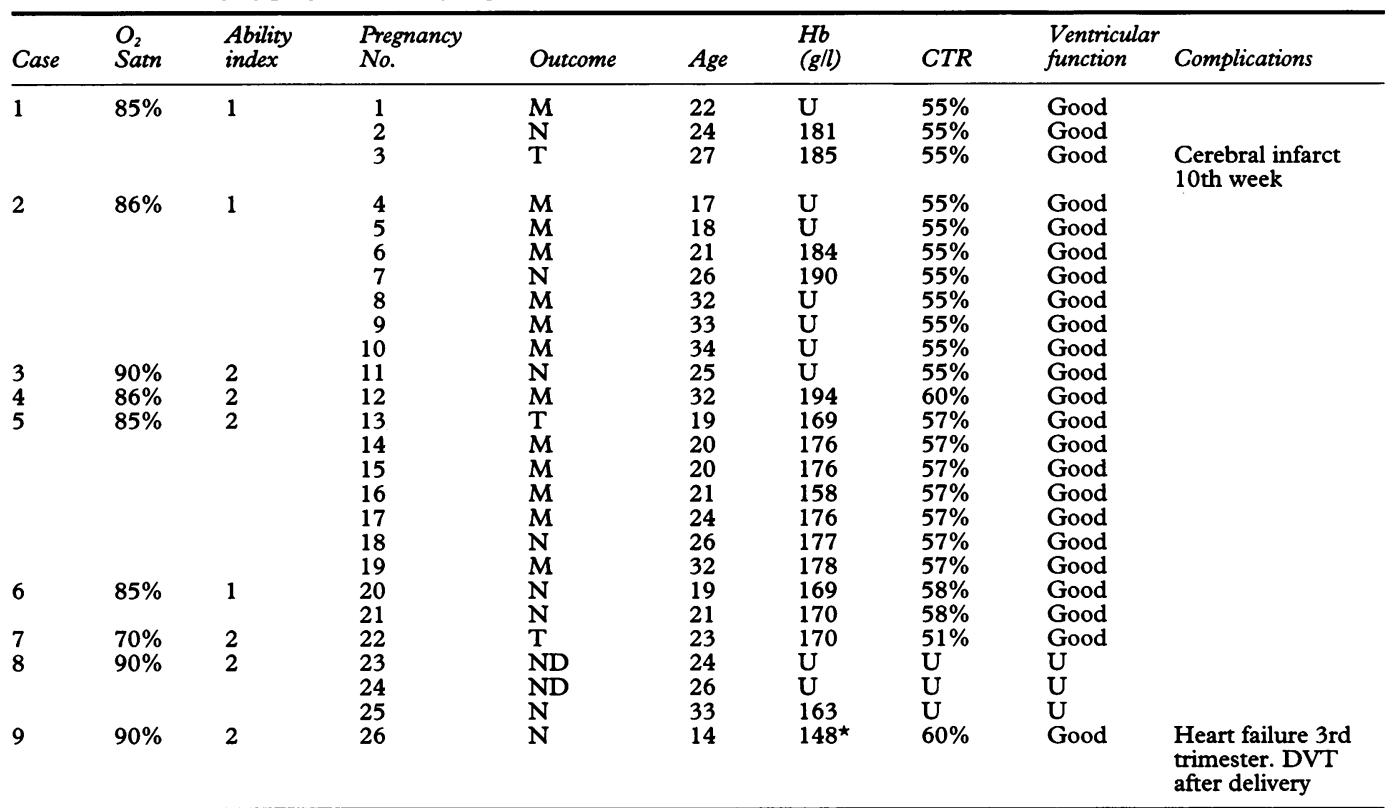

$\mathrm{O}_{2}$ Satn, arterial oxygen saturation; CTR, cardiothoracic ratio on chest radiograph; DVT, deep venous thrombosis; Hb, haemoglobin; M, miscarriage between 8 and 12 weeks; N, normal child; ND, neonatal death; T, termination; U, unknown.

^At 28 weeks’ gestation.

Table 3 Summary of pregnancies in group II

\begin{tabular}{|c|c|c|c|c|c|c|c|c|c|c|c|}
\hline Case & $\begin{array}{l}\text { Radical } \\
\text { repair }\end{array}$ & $\begin{array}{l}\text { Residual } \\
\text { VSD }\end{array}$ & $\begin{array}{l}\text { Residual } \\
\text { collaterals }\end{array}$ & $\begin{array}{l}R V P \\
P A P \\
(m m \mathrm{Hg})\end{array}$ & $\begin{array}{l}\text { Age at } \\
\text { surgery } \\
\text { (years) }\end{array}$ & $\begin{array}{l}\text { Pregnancy } \\
\text { No. }\end{array}$ & Outcome & $\begin{array}{l}\text { Age at } \\
\text { pregnancy }\end{array}$ & $A I$ & $C T R$ & Complications \\
\hline \multirow[t]{2}{*}{9} & \multirow{2}{*}{$\begin{array}{l}\text { Dacron } \\
\text { conduit }+ \\
\text { homograft } \\
\text { valve }\end{array}$} & \multirow[t]{2}{*}{+} & \multirow[t]{2}{*}{+} & \multirow[t]{2}{*}{$\begin{array}{l}70 / 10 \\
85 / 30\end{array}$} & \multirow[t]{2}{*}{18} & 27 & $\mathbf{N}$ & 19 & 1 & $60 \%$ & $\begin{array}{l}\text { VEBs during } \\
\text { pregnancy and } \\
\text { 1 st year after }\end{array}$ \\
\hline & & & & & & 28 & $\mathbf{N}$ & 23 & 1 & $60 \%$ & - \\
\hline \multirow[t]{2}{*}{10} & \multirow{2}{*}{$\begin{array}{l}\text { Dacron } \\
\text { conduit }+ \\
\text { calf } \\
\text { pericardial } \\
\text { valve }\end{array}$} & \multirow[t]{2}{*}{-} & \multirow[t]{2}{*}{-} & \multirow{2}{*}{$\begin{array}{l}120 / 10 \\
28 / 10\end{array}$} & \multirow[t]{2}{*}{17} & 29 & $\mathbf{M}$ & 23 & 2 & $55 \%$ & - \\
\hline & & & & & & 30 & $\mathbf{N}^{\star}$ & 26 & 2 & $55 \%$ & - \\
\hline \multirow[t]{2}{*}{11} & \multirow[t]{2}{*}{$\begin{array}{l}\text { Dacron } \\
\text { conduit }+ \\
\text { calf } \\
\text { pericardial } \\
\text { valve }\end{array}$} & + & \multirow[t]{2}{*}{+} & \multirow[t]{2}{*}{$\begin{array}{l}65 / 1 \\
60 / 25\end{array}$} & \multirow[t]{2}{*}{12} & 31 & CHD & 16 & 1 & $64 \%$ & $\begin{array}{l}\text { LVF 3rd } \\
\text { trimester } \\
\text { PE 12 } \\
\text { days after } \\
\text { delivery }\end{array}$ \\
\hline & & & & & & 32 & $\mathbf{N}$ & 22 & $1 \rightarrow 2$ & $64 \%$ & $\begin{array}{l}\text { LVF 3rd } \\
\text { trimester } \\
\text { persistent } \\
\text { afterwards }\end{array}$ \\
\hline 12 & $\begin{array}{l}\text { Dacron } \\
\text { conduit }+ \\
\text { calf } \\
\text { pericardial } \\
\text { valve }\end{array}$ & - & - & $\begin{array}{l}100 / 8 \\
25 / 8\end{array}$ & 11 & 33 & $\mathbf{N}$ & 20 & 1 & $55 \%$ & - \\
\hline \multirow[t]{3}{*}{13} & \multirow{3}{*}{$\begin{array}{l}\text { Uncertain } \\
\text { (pericardium } \\
\text { or other } \\
\text { autologous } \\
\text { material) }\end{array}$} & \multirow[t]{3}{*}{-} & \multirow[t]{3}{*}{+} & \multirow[t]{3}{*}{$\begin{array}{l}85 / 12 \\
65 / 8\end{array}$} & \multirow[t]{3}{*}{20} & 35 & $\mathbf{M}$ & 20 & 2 & $\mathrm{U}$ & - \\
\hline & & & & & & 36 & CHD & 21 & 2 & $\mathrm{U}$ & $\begin{array}{l}\text { LVF 3rd } \\
\text { trimester }\end{array}$ \\
\hline & & & & & & 37 & $\mathbf{N}$ & 23 & 2 & $\mathrm{U}$ & $\begin{array}{l}\text { LVF 3rd } \\
\text { trimester }\end{array}$ \\
\hline \multirow[t]{2}{*}{14} & \multirow{2}{*}{$\begin{array}{l}\text { Dacron } \\
\text { conduit }+ \\
\text { homograft } \\
\text { valve }\end{array}$} & \multirow[t]{2}{*}{-} & \multirow[t]{2}{*}{+} & \multirow[t]{2}{*}{$\begin{array}{l}50 / 6 \\
47 / 25\end{array}$} & \multirow[t]{2}{*}{12} & 38 & $\mathbf{N}$ & 22 & 1 & $50 \%$ & - \\
\hline & & & & & & 39 & $\mathbf{N}$ & 24 & 1 & $50 \%$ & - \\
\hline 15 & $\begin{array}{l}\text { Dacron } \\
\text { conduit }+\end{array}$ & - & + & $\begin{array}{l}63 / 4 \\
34 / 11\end{array}$ & 24 & 40 & $\mathbf{N}$ & 26 & 1 & $58 \%$ & - \\
\hline & $\begin{array}{l}\text { homograft } \\
\text { valve }\end{array}$ & & & & & 41 & $\mathbf{N}$ & 30 & $1 \rightarrow 3$ & $\begin{array}{l}58 \rightarrow \\
68 \%\end{array}$ & $\begin{array}{l}\text { LVF 3rd } \\
\text { trimester, } \\
\text { progressive } \\
\text { afterwards } \\
\text { Death } 13 \\
\text { months later }\end{array}$ \\
\hline
\end{tabular}

AI, ability index; CHD, child with congenital heart disease; CTR, cardiothoracic ratio on chest radiograph; LVF, left ventricular failure; $\mathrm{M}$, miscarriage; N, normal child; PAP, pulmonary artery pressure; PE, pulmonary embolism; RVP, right ventricle pressure; U, unknown; VEBs, ventricular ectopic beats; VSD, ventricular septal defect. 
Table 4 Summary of terminations performed in three patients with complex pulmonary atresia

\begin{tabular}{lclll}
\hline Case & Pregnancy No. & Weeks of gestation & Reason for termination & Outcome \\
\hline 1 & 3 & 10 & Left cerebral infarct & $\begin{array}{l}\text { Full recovery on } \\
\text { anticoagulants }\end{array}$ \\
5 & 13 & 15 & $\begin{array}{l}\text { Recent bacterial } \\
\text { endocarditis } \\
\text { Dyspnoea }\end{array}$ & $\begin{array}{l}\text { No change } \\
\text { Systemic oxygen } \\
\text { saturation 70\% } \\
\text { Awaiting shunt }\end{array}$ \\
7 & 22 & 8 & $\begin{array}{l}\text { Blalock-Taussig } \\
\text { shunt one week } \\
\text { later }\end{array}$ \\
\hline
\end{tabular}

before or at the beginning of the pregnancy (unknown in six miscarriages and in three successful pregnancies), ability index, heart size on chest radiograph (unknown in one patient), and right and left ventricular function (unknown in one patient) before and in the first year after the pregnancy, complications during and in the first year after the pregnancy, gestational age, method of delivery (unknown in two pregnancies), birthweight (unknown in two pregnancies), and malformations in the fetus. None of the fetuses of the pregnancies which ended in miscarriage or termination was examined.

\section{GROUP II}

Seven patients (cases 9-15) who had had radical repair with 15 pregnancies (pregnancies 27-41) constituted group II (table 3). Two pregnancies (27 and 28 ) occurred in case 9 who entered group II after she had a complete repair. No patient was cyanosed at rest and all had normal haemoglobin concentrations. Different material had been used for the radical repair (table 3). Three patients (cases 13-15) had residual systemic-pulmonary collaterals, two (cases 9 and 11) had small residual ventricular septal defects and collaterals, and two (cases 10 and 12) had no known residual lesions.

For each pregnancy the following data were noted: patient's age at complete repair and at the beginning of the pregnancy; residual lesions, right ventricular and pulmonary artery pressure, ability index, heart size on chest radiograph (unknown in one patient), right and left ventricular function (unknown in two patients) before and in the first year after the pregnancy, complications during and in the first year after the pregnancy, gestational age (unknown in one pregnancy), method of delivery (unknown in one pregnancy), birthweight (unknown in one pregnancy and said to be normal in two pregnancies), and malformations in the fetus. Nothing was known about the fetuses of pregnancies ended by miscarriage.

\section{Results}

\section{FETAL OUTCOME}

Group I

Three pregnancies were terminated $(3,13$, and 22) (table 4), 13 resulted in miscarriages at eight to 12 weeks, and eight in delivery of healthy children (table 5), all female; two further female babies (pregnancies 23 and 24) born to one patient (case 8 ) in Pakistan and presumed to be normal (according to the local doctor) died suddenly as neonates; one (pregnancy 24) was born prematurely at 30 weeks but no necropsies were performed. The babies' gestational age was between 30 and 39 weeks (under 36 weeks in five; mean 34.5; unknown in two pregnancies), and the birthweights were between 1290 and $2395 \mathrm{~g}$ (mean $1846 \mathrm{~g}$; unknown in two children). Only one child was delivered by caesarean section, forceps were used in four, and presentation was breech in three pregnancies (table 5).

Table 6 compares the miscarriages and successful pregnancies in each patient in group I. There were no miscarriages in the three patients (cases 3, 8, and 9) whose oxygen saturations were around $90 \%$. The pregnancy of one patient (case 7) who had a systemic oxygen saturation of $70 \%$ was terminated at eight weeks because she was awaiting a BlalockTaussig shunt. In the patients with saturations around $85 \%$ the outcome of the pregnancies

Table 5 Successful pregnancies in patients with complex plumonary atresia

\begin{tabular}{|c|c|c|c|c|c|c|}
\hline Case & Pregnancy No. & Weeks of gestation & Type of delivery & Weight (g) & Sex & Outcome \\
\hline \multicolumn{7}{|l|}{ Group I } \\
\hline 1 & 2 & 37 & Forceps & 2100 & $\mathbf{F}$ & $\mathbf{H}$ \\
\hline 2 & 7 & 36 & Normal & 2330 & $\mathrm{~F}$ & $\mathrm{H}$ \\
\hline 3 & 11 & 35 & Normal & 1930 & $\mathbf{F}$ & $\mathbf{H}$ \\
\hline 5 & 18 & 31 & $\begin{array}{l}\text { Caesarean } \\
\text { (growth retard) }\end{array}$ & 1030 & $\mathbf{F}$ & $\mathbf{H}$ \\
\hline 6 & 20 & 38 & Forceps (breech) & 2260 & $\mathbf{F}$ & $\mathbf{H}$ \\
\hline & 21 & 39 & Forceps & 2395 & F & $\mathrm{H}$ \\
\hline 8 & 23 & 37 & Unknown & Unknown & $\mathbf{F}$ & $? \mathrm{H} \rightarrow \mathrm{ND}$ \\
\hline & 24 & 30 & Unknown & Unknown & $\mathbf{F}$ & $? \mathrm{H} \rightarrow \mathrm{ND}$ \\
\hline & 25 & 31 & Vaginal (breech) & 1290 & $\mathbf{F}$ & \\
\hline 9 & 26 & 33 & Forceps (breech) & 1430 & $\mathbf{F}$ & $\mathbf{H}$ \\
\hline \multicolumn{7}{|l|}{ Group II } \\
\hline 9 & 27 & 39 & Normal & 3310 & $\mathbf{M}$ & $\mathbf{H}$ \\
\hline & 28 & 36 & Normal & 2750 & $\mathrm{~F}$ & $\mathrm{H}$ \\
\hline 10 & $30^{\star}$ & 40 & Normal & 3524 & $\mathrm{~F}$ & $\mathbf{H}$ \\
\hline \multirow[t]{2}{*}{11} & 31 & 42 & Forceps & 2718 & $\mathbf{M}$ & Truncus \\
\hline & 32 & 38 & Normal & 3330 & $F$ & $\mathrm{H}$ \\
\hline \multirow[t]{2}{*}{12} & 33 & 40 & Normal & Normal & $\mathrm{U}$ & $\mathbf{H}$ \\
\hline & 34 & 40 & Normal & Normal & $\mathrm{U}$ & $\mathbf{H}$ \\
\hline \multirow[t]{2}{*}{13} & 36 & 39 & Forceps & 2916 & $\mathbf{M}$ & PDA \\
\hline & 37 & 38 & Normal & 2831 & $\mathbf{M}$ & $\mathbf{H}$ \\
\hline \multirow[t]{2}{*}{14} & 38 & 39 & Caesarean & 3000 & $\mathbf{F}$ & $\mathbf{H}$ \\
\hline & 39 & 40 & Caesarean & 2831 & $F$ & $\mathbf{H}$ \\
\hline \multirow[t]{2}{*}{15} & 40 & 41 & Normal & 3539 & $\mathbf{M}$ & $\mathbf{H}$ \\
\hline & 41 & Unknown & Unknown & Unknown & $\mathbf{M}$ & $\mathbf{H}$ \\
\hline
\end{tabular}


Table 6 Comparison between miscarriages and successful pregnancies in group I patients with complex pulmonary atresia

\begin{tabular}{|c|c|c|c|c|c|c|c|c|}
\hline \multirow[b]{2}{*}{ Case } & \multirow{2}{*}{$\begin{array}{l}\text { Arterial } \\
\text { oxygen } \\
\text { saturation }\end{array}$} & \multirow[b]{2}{*}{$\begin{array}{l}\text { Ability } \\
\text { index }\end{array}$} & \multicolumn{3}{|c|}{ Miscarriages } & \multicolumn{3}{|c|}{ Successful pregnancies } \\
\hline & & & $\begin{array}{l}\text { Maternal } \\
\text { age }\end{array}$ & $\begin{array}{l}H b \\
(g / l)\end{array}$ & $\begin{array}{l}\text { Pregnancy } \\
\text { No. }\end{array}$ & $\begin{array}{l}\text { Maternal } \\
\text { age }\end{array}$ & $\begin{array}{l}H b \\
(g / l)\end{array}$ & $\begin{array}{l}\text { Pregnancy } \\
\text { No. }\end{array}$ \\
\hline $\begin{array}{l}1 \\
2\end{array}$ & $\begin{array}{l}85 \% \\
85 \%\end{array}$ & $\begin{array}{l}1 \\
1\end{array}$ & $\begin{array}{l}22 \\
17 \\
18 \\
21 \\
32 \\
33 \\
34\end{array}$ & $\begin{array}{l}\text { Unknown } \\
\text { Unknown } \\
\text { Unknown } \\
184 \\
\text { Unknown } \\
\text { Unknown } \\
\text { Unknown }\end{array}$ & $\begin{array}{r}1 \\
4 \\
5 \\
6 \\
8 \\
9 \\
10\end{array}$ & $\begin{array}{l}24 \\
26\end{array}$ & $\begin{array}{l}181 \\
190\end{array}$ & $\begin{array}{l}2 \\
7\end{array}$ \\
\hline $\begin{array}{l}3 \\
4\end{array}$ & $\begin{array}{l}90 \% \\
86 \%\end{array}$ & 2 & & & & 25 & Unknown & 11 \\
\hline $\begin{array}{l}4 \\
5\end{array}$ & $\begin{array}{l}86 \% \\
85 \%\end{array}$ & $\begin{array}{l}2 \\
2\end{array}$ & $\begin{array}{l}32 \\
20 \\
20 \\
21 \\
24 \\
25\end{array}$ & $\begin{array}{l}194 \\
169 \\
176 \\
158 \\
176 \\
178\end{array}$ & $\begin{array}{l}12 \\
14 \\
15 \\
16 \\
17 \\
19\end{array}$ & 26 & 177 & 18 \\
\hline 6 & $85 \%$ & 1 & & & & $\begin{array}{l}19 \\
21\end{array}$ & $\begin{array}{l}169 \\
170\end{array}$ & $\begin{array}{l}20 \\
21\end{array}$ \\
\hline 8 & $90 \%$ & 2 & . & & & $\begin{array}{l}24 \\
26 \\
33\end{array}$ & $\begin{array}{l}\text { Unknown } \\
\text { Unknown } \\
163\end{array}$ & $\begin{array}{l}23 \\
24 \\
25\end{array}$ \\
\hline 9 & $90 \%$ & 2 & & & & 14 & $142^{\star}$ & 26 \\
\hline
\end{tabular}

$\mathrm{Hb}$, haemoglobin.

$\star$ Patient was 28 weeks pregnant when first seen.

could not be related to maternal age, ability index, nor haemoglobin concentration, and there were no significant differences in gestational age and birthweight in relation to these parameters.

\section{Group II}

No pregnancy was terminated, two patients miscarried at eight and 10 weeks (pregnancies 29 and 35), 11 babies were normal, and two had congenital heart disease (pregnancies 31 and 36). The children were born between 36 and 42 weeks of gestation (mean 39.3; unknown in one pregnancy), birthweights were between 2718 and $3539 \mathrm{~g}$ (mean $3072 \mathrm{~g}$; unknown in three). Delivery was normal in eight pregnancies, assisted (forceps) in two and by caesarean section in two pregnancies (unknown in one pregnancy) (table 5). One of the babies with congenital heart disease (pregnancy 31) had a truncus type I and died following surgery at three weeks of age; the other (pregnancy 36) had a persistent duct and is well following ligation. One miscarriage in this group (pregnancy 29) occurred in a grossly obese patient who subsequently complained of infertility and conceived her second pregnancy (pregnancy 30) after in vitro fertilisation, resulting in a normal baby. There was no apparent reason for the other miscarriage (pregnancy 35) although the patient was grossly obese.

\section{MATERNAL OUTCOME}

Group I

Maternal age was between 14 and 34 years. All patients had at least mildly elevated haemoglobin concentrations, varying between 161 and $190 \mathrm{~g} / 1$ (unknown in six miscarriages and in three successful pregnancies). Three patients had an ability index of 1 , and six patients had an ability index of 2 ; these were unchanged after their pregnancies. All patients had slightly or moderately increased heart size on the chest radiograph (cardiothoracic ratio $51-60 \%$, unknown in one patient), but it did not change significantly during and after the pregnancies. Ventricular function was judged as good at echocardiographic examination before pregnancy in all patients (unknown in one) and no change could be attributed to the pregnancy (table 2). Two patients had important complications. Case 1 developed left cerebral infarction 10 weeks into her third pregnancy (pregnancy 3); the pregnancy was terminated and the mother made a complete recovery on anticoagulants. Case 9 developed breathlessness during the third trimester of her first pregnancy (pregnancy 26) that required hospitalisation and treatment with diuretics; after delivery she developed deep venous thrombosis and was anticoagulated.

\section{Group II}

Maternal age was between 16 and 30 years. Complete repair had been performed between ages 11 and 24 years; the interval between the repair and the pregnancy varied from six months to 13 years (mean six years). Five patients had an ability index of 1 before their pregnancies; in cases 10 and 13 ability indices were evaluated as 2 in relation to their marked obesity and not to their cardiac problems. Right ventricular pressure was moderately elevated in five patients (cases 9, 11, and 13-15) before their pregnancies in the absence of a significant gradient in the right ventricular outflow tract; case 13 also had significant pulmonary regurgitation. Heart size was slightly to moderately enlarged in all patients (cardiothoracic ratio of $50-64 \%$ ), right and left ventricular function (as assessed by echocardiography) was judged as good in five patients before their first pregnancy (unknown in cases 13 and 15). Three patients (cases 10,12, and 14) had six uncomplicated pregnancies. Two of them (cases 10 and 12) were found to have gradients of $80-100 \mathrm{~mm} \mathrm{Hg}$ across the right ventricular outflow tract with normal pulmonary artery pressure after their pregnancies, but as they had not been previously investigated these findings could not be clearly related to the pregnancies. One patient (case 9) developed symptomatic ventricular ectopic beats during and immediately after her first pregnancy. Three patients (cases 11, 13, and 
15) experienced left ventricular failure during five pregnancies (pregnancies 31 and 32, 36 and 37 , and 41 ), requiring hospitalisation and intravenous diuretics. In addition, case 11 suffered a pulmonary embolism after her first pregnancy, and after her second pregnancy she continued to complain of breathlessness and palpitations requiring digoxin and diuretics. Case 15 continued to deteriorate after her second pregnancy (pregnancy 41) and died from heart failure 13 months after delivery; this patient had a fistulous communication between the left coronary artery and the pulmonary artery, ligated during the complete repair six years earlier. Five patients maintained their ability index ( 1 or 2), but cases 11 and 15 deteriorated to ability index 2 and 3-4, respectively, after their second pregnancy. Heart size on chest radiography increased significantly in case 15 only, during and after her second pregnancy. In patients who experienced significant left ventricular failure, left ventricular function (assessed by echocardiography) continued to be impaired after the pregnancy. All patients who experienced complications had residual systemic-pulmonary collaterals, with or without residual ventricular septal defect, moderately elevated right ventricular pressure without significant outflow tract gradients, and larger hearts on the chest radiograph (cardiothoracic ratio of $58 \%$ or more; unknown in one patient) (table 3 ).

\section{Discussion}

There are previous studies and case reports on pregnancies in patients with repaired tetralogy of Fallot ${ }^{5}$ and patients with cyanotic heart disease of various types, ${ }^{6-8}$ but the outcome of pregnancies in patients with this particular anomaly, compatible with survival to reproductive age with or without surgery, has not been investigated.

This study shows that patients with complex pulmonary atresia with no or mild symptoms (ability index 1 or 2) can complete successful pregnancies before and after surgical repair. However, it appears there are different maternal and fetal risks in the two groups. Complications in group I who had not had radical repair occurred mainly in the fetus, such as have been described in cyanotic patients. ${ }^{6}$ Excluding pregnancies that were terminated, 13 of 23 pregnancies $(56.5 \%)$ resulted in miscarriage. All occurred in patients whose systemic oxygen saturation was $85 \%$ or less at cardiac catheterisation. ${ }^{6}$ Whether there were fetal malformations in the miscarriage group is unknown. Five of the 10 live born infants (50\%) were born before 36 weeks of gestation and the other five were born between 36 and 38 weeks'; all had low birthweights, a known effect of maternal cyanosis. In group I there were few maternal complications. One thromboembolic complication occurred in the 10th week of pregnancy, and right ventricular failure in the third trimester of another pregnancy soon resolved with rest and diuretics. In patients with unrepaired complex pulmonary atresia there could be concern about a degree of pulmonary hypertension that might increase during pregnancy. At least five of the patients (cases 3-7) had high pressure in one lung or part of it and low pressures in the rest of the lungs, as some collaterals were stenosed at their origin. We do not know whether the pulmonary artery pressures increased during or after pregnancies as catheters were not repeated. Without clinical change a significant increase seems unlikely, therefore we do not consider it necessary to catheterise patients routinely who are well before a pregnancy.

In group II, after surgical repair, fetal outcome was radically improved with only two miscarriages in 15 pregnancies (13.3\%). Babies were born after 36 weeks of gestation and birthweights were significantly higher than in group I. However, there were more complications in the mothers in this group. Symptomatic ventricular ectopic beats occurred in one patient and pulmonary embolism in another. Three patients developed left ventricular failure that persisted after the pregnancy in one case and was progressive in another, leading to death one year after delivery. Patients with residual systemic-pulmonary collaterals, elevated right ventricular pressure in the absence of right ventricular outflow tract obstruction, and large hearts on the chest radiograph appeared to be at particularly high risk. It is important in this group carefully to assess ventricular function before the pregnancy and to monitor it closely during the pregnancy and in the first year after, particularly if residual lesions are present.

The usual criteria of assessing ventricular function by echocardiography (fraction of shortening and ejection fraction) often are not reliable in patients with complex congenital heart disease where ventricular dimensions and septal movement are usually abnormal. Thus, unfortunately, we cannot provide from our data numbers or measurements defining patients whose ventricular function is well enough to tolerate a pregnancy. We believe that unless ventricular function appears significantly impaired, a pregnancy is possible if the mother is monitored closely. Any signs of failure must be treated aggressively, first with rest and diuretics, if necessary with inotropes.

Thrombotic complications occurred in patients before and after surgical repair. Therefore, being particularly aware of this complication, the use of physical measures to prevent it (stockings, exercise) is mandatory. None of our patients received prophylactic low dose aspirin, warfarin or heparin; these drugs carry a high risk in cyanotic patients, ${ }^{9}$ but it would be important to investigate their use in this particular situation.

We do not know to what extent a pregnancy contributes to increasing a gradient in the right ventricular outflow tract in all patients. Two patients had severe gradients after successful, uncomplicated pregnancies, but we have no evidence that pregnancy had increased the obstruction by increase in calcification.

In this series two children were identified as having congenital heart disease $(8 \cdot 7 \%$ of live 
births), one a patent duct and another an arterial trunk. Other series have found a higher ${ }^{10}$ or lower ${ }^{6}$ incidence. Because of the high number of early losses that were not examined, the real incidence of congenital heart disease in these patients is unknown and is likely to be higher.

An interesting aspect is the preponderance of female children in group I patients (before surgical repair). All 10 live births were female. In the group after surgical repair the distribution was equal (six male and five female babies, unknown in two). Whether this is a casual finding or cyanosis predisposes to production of females needs to be investigated. Bacterial endocarditis did not occur in any of our patients, despite delivery being assisted in six and caesarean sections being performed in three pregnancies (unknown in three pregnancies). We recommend prophylaxis when the membranes rupture but do not know how many patients had received antibiotics as it was mentioned in only three reports.

Patients with complex pulmonary atresia without surgical repair can go through pregnancies with low risk to themselves but high incidence of fetal complications. After radical repair fetal outcome is similar to that in the normal population but mothers have a definitive risk of left ventricular failure which must be recognised and prevented, particularly in the presence of residual systemic-pulmonary collaterals.

1 Ross DN, Somerville J. Correction of pulmonary atresia with a homograft aortic valve. Lancet 1966;ii:1446-7.

2 Sawatari K, Imai Y, Kurosawa H, Isomatsu Y, Momma K Staged operation for pulmonary atresia and ventricular septal defect with major aortopulmonary collateral arteries. New technique for complete unifocalization. $\mathcal{F}$ Thorac Cardiovasc Surg 1989;98:738-50.

3 Norwood WI, Freed MD, Rocchini AP, Bernhard WF, Castaneda AR. Experience with valved conduits for repair of congenital cardiac lesions. Ann Thorac Surg 1977;24:223-32.

4 Somerville J. Clinical identification of the pulmonary blood supply in pulmonary atresia. In: Anderson RH, Neches WH, Park SC, Zuberbuhler JR, eds. Perspectives in paediatric cardiology. Mount Kisco: Futura Publishing Co, atric cardiolo

5 Singh H, Bolton PJ, Oakley CM. Pregnancy after surgical correction of tetralogy of Fallot. BMF 1982;285:168-70.

6 Presbitero P, Somerville J, Stone S, Aruta E, Spiegelhalter D, Rabajoli F. Pregnancy in cyanotic congenital heart disease. Outcome of mother and fetus. Circulation 1994; 98:2673-6.

7 Frenkel Y, Alcalay M, Chayen B, Blieden L, Mashiach S, Battler A. Successful pregnancy in a woman with cyanotic congenital heart disease after a palliative pulmonarysystemic shunt. A case report. $\mathcal{F}$ Reproductive Med 1994; 39:566-8.

8 Zavisca FG, Johnson MD, Holubec JT, Kao YJ, Racz GB General anesthesia for cesarean section in a parturient with a single ventricle and pulmonary atresia. $\mathcal{F}$ Clin Anesthesia 1993;5:315-20.

9 Territo MC, Rosove M, Perloff JK. Cyanotic congenital heart disease. In: Perloff JK, Child JS, eds. Congenital heart disease in adults. Philadelphia: WB Saunders Co, heart disease in

10 Whittemore R, Hobbins JC, Engle MA. Pregnancy and its outcome in women with and without surgical treatment of congenital heart disease. Am $\mathcal{F}$ Cardiol 1982;50: 641-51. 